\title{
ROLE OF IONIZING RADIATION ON CONTROLLING KIDNEY CHANGES IN EXPERIMENTAL INFECTION WITH TOXOCARA CANIS
}

\author{
MERVAT A. MOAWAD, MONA M. AMIN and EMAN N. HAFEZ \\ Health Radiation Research Dept., National Centre for Radiation Research and Technology (NCRRT), \\ Tel. +201068429907, Mailing P. O. Box: 29 Nasr City, Egypt.
}

Email: Eman_naser612@hotmail.com

Assiut University web-site: $\underline{\text { www.aun.edu.eg }}$

\section{ABSTRACT}

Received at: 16/9/2015

Accepted: 30/9/2015
Toxocara canis (T.canis) is an important parasite that infects many domestic and farm animals whose economical importance cannot be neglected. The aim of the present study is to detect the hematological, biochemical and histopathological changes on kidney of rats vaccinated with two doses of gamma radiation (600Gy and 800Gy) embryonated eggs. Eighty rats were divided into four groups group I: as normal control group (-ve control), group II: received 2500 infective embryonated $T$. canis eggs per $\mathrm{ml} / \mathrm{rat}$ orally, as control infected (+ve control), group III: received 600 Gy irradiated T.canis eggs, group IV: received 800 Gy irradiated T. canis eggs, However, at $14^{\text {th }}$ day post infection, rats were re-infected (challenged) with nonirradiated infective T.canis eggs. The study showed marked histopathological changes with significant decrease of glutathione (GSH) and superoxide dismutase (SOD) and remarkable increase of lipid peroxidation (MDA) in kidney tissue of infected control group. Also, marked increase in urea, creatinine and total proteins with decrease in albumin in control infected group. Vaccinated-challenged group III and IV showed amelioration in all histopathological, biochemical and hematological changes. Radiation exposure attenuated the larval migration from the gastrointestinal tract to other organs and controls the damaging effect on the kidney. The dose of 800Gy showed better results than lower dose.

Key wards: Toxocara canis; Kidney; Antioxidents; gamma radiation; vaccination

\section{INTRODUCTION}

Toxocara canis is a nematode whose biological cycle includes its definitive canine host, the environment and paratenic hosts, which include man, rats, rabbits, birds and pigs (Glickman, 1993). Toxocariasis is considered an aberrant infection because humans are incidental hosts, and the arasite cannot completely mature in the human body (Alderet et al., 1999 and Alonso et al., 2000). Instead the invasive larvae migrate for months through distant organs including brain, heart, lungs, kidney, muscles and eye (Fortenberry et al., 1991) until they are overcome by the human inflammatory reaction and die. Some are destroyed in the liver or pass onto the lung and destroyed there (Rothenberg, 1998), while others can survive in tissues for at least nine years and possibly for life of the host (Pawlowski, 2007). The mode of transmission to humans is by oral ingestion of infective eggs (Glickman et al., 1981). Three clinical syndromes have been associated with Toxocara infection in humans; visceral larva migrans (VLM), ocular larva migrans (OLM) and covert toxocariasis Taylor and Holland, 2001). The oxidative stress status was determined by measuring serum malondialdehyde (MDA) level as indicator of lipid peroxidation, erythrocytes superoxide dismutase (SOD) and glutathione (GSH) as indicators of endogenous antioxidant enzymes level. Potential mechanisms and roles of oxidative stress have also been investigated in a number of parasitic diseases. Brugia malayi has been found relatively resistant to nitric oxide (NO) mediated toxicity (Rajan et al., 1996). Lipid peroxidase product has been measured showing a significant increase in Schistosoma mansoni infected mice, and values have been partially restored after antioxidant melatonin application (ElSokkary et al., 2002). Oxidative stress as a mediator of hepatic tissue damage related to Leishmania chagasi infection has been investigated, and a significant correlation between occurrence of oxidative stress and lipid peroxidation as a mechanism of liver damage and tissue injury has been reported in the chronic stage of infection (Oliveira and Cecchini, 2000). Enzymatic and non-enzymatic antioxidants have been reported from filarial 
nematodes and this group has been suggested as relatively resistant to oxidative stress (Selkirk et al., 1998). Visceral larva migrans (VLM) caused by Toxocara spp. larvae is an important systemic parasitic disease of humans. It affects most of the organs and causes responsive changes and tissue damage in infected individuals (Espinosa et al., 2002). Most studies on irradiation of pathogenic organisms have been carried out primarily with the aim of establishing an attenuated vaccine. One of the developing and hopeful routes of vaccination is to use feeble irradiated parasite as a vaccinating antigen. The parasites studied for this purpose include Toxocara canis (Kamiya et al., 1987).

This work aimed to detect hematological, biochemical and histopathological changes in kidney of toxocariasis infected mice and determine the effect of vaccination with $600 \mathrm{~Gy}$ and $800 \mathrm{~Gy}$ gamma radiation-irradiated Toxocara canis eggs in controlling these changes.

\section{MATERIALS and METHODS}

\section{Animals}

Male albino rats weighing 100-160 gm, each of the same colonies were used. 80 rats were kept in the laboratory at room temperature and housed in cages (10 rats in each cage). Rats received a diet of standard rodent pellets produced by the Cairo Company for Oil and Soap. Water and food were available ad libitum.

\section{Preparation of embryonated eggs of parasite}

T. canis embryonated eggs were obtained from the uteri of female nematodes collected from the naturally infected dogs. Eggs were incubated in $0.5 \%$ formalin solution at $28^{\circ} \mathrm{C}$ for 4 weeks. Embryonated eggs were kept at $+4^{\circ} \mathrm{C}$ until used. Rat in the VLM groups were each infected with 2500 embryonated eggs (Galvin, 1964).

\section{Radiation source:}

Toxocara eggs were exposed to 600Gy and 800Gy gamma-radiations rays at dose rat $2.5 \mathrm{KGy} / \mathrm{h}$ at the time of experiment. This was done in national Center for Radiation Research and Technology (NCRRT), Cairo, Egypt.

\section{Infection of rats}

The experiment was run in groups; each group consisted of 20 rats, first group was used as control group, second group: each animal received orally infective embryonated $T$. canis eggs (2500 infective eggs per $\mathrm{ml} / \mathrm{rat}$ ), third group: received the same number of 600Gy irradiated infective T. canis eggs, fourth group: received $800 \mathrm{~Gy}$ irradiated infective T. canis eggs. However, at $14^{\text {th }}$ day post infection, rats were re-infected (challenged) with non-irradiated infective $T$. canis eggs (2500 eggs/rat). Five rats were scarified at the $7^{\text {th }}$ and $14^{\text {th }}$ days after first infection also, at the $7^{\text {th }}$ and $14^{\text {th }}$ day post challenge. Serum was separated, from blood by centrifugation at $3000 \mathrm{rpm}$ for 10-15 minutes and utilized for the measurement of biochemical parameters. Kidney was removed for biochemical analysis and histopathological study. The homogenates of kidney tissues $(10 \%)$ were prepared in normal saline for biochemical study.

\section{Biochemical study:}

Blood biochemistry values were measured by use of an automated spectrophotometer and included urea $(\mathrm{mg} / \mathrm{dl})$, creatine $(\mathrm{mg} / \mathrm{dl})$, total proteins $(\mathrm{g} / \mathrm{dl})$, albumin $(\mathrm{g} / \mathrm{dl})$. Values were taken as normal for blood biochemistry (Kaneko, 1989).

Measurement of the lipid peroxidation: Tissue TBARS (thiobarbituric acid reacting substances) levels as the marker of lipid peroxidation were determined with the spectrophotometric method. Stock solution: $15 \%$ trichloroacetic acid (TCA), $0.375 \%$ thiobarbituric acid (TBA), 0.25 of $\mathrm{N}$ hydrochloric acid $(\mathrm{HCl})$. Samples were heated in a water bath for $20 \mathrm{~min}$ and after cooling, centrifuged at 2,000 rpm for $15 \mathrm{~min}$. The formation of pink color, as a result of the reaction in-between one molecule of TBARS and two molecules of TBA, was measured at $560 \mathrm{~nm}$ spectrophotometrically (Buege and Aust, 1978).

Measurement of the tissue SOD activity: Tissue super oxide dismutase activity was measured by modified method. This assay for super oxide dismutase activity involved inhibition of nitroblue tetrazolium (NBT) reduction, with xanthine oxidase used as a super oxide generator. One unit SOD was defined as the amount of protein that inhibits the rate of NBT reduction by $50 \%$. Reaction mixture: $40 \mathrm{ml}$ of 0.3 mmol/l xanthine solution, $20 \mathrm{ml}$ of $0.6 \mathrm{mmol} / \mathrm{l}$ EDTA solution, $20 \mathrm{ml}$ of $150 \mu \mathrm{mol} / 1$ nitroblue tetrazolium solution, $12 \mathrm{ml}$ of $400 \mathrm{mmol} / \mathrm{l} \mathrm{Na} 2 \mathrm{CO} 3$ solution, and $6 \mathrm{ml}$ of bovine serum albumin. The final concentration of xanthine oxidase was $167 \mathrm{U} / \mathrm{l}$. The production of formazon was determined at $560 \mathrm{~nm}$, spectrophotometrically. Measurement of glutathione was determined according (Sun et al., 1988 and Beutler et al., 1963).

\section{Histopathology}

After proper fixation of kidney tissues, thin pieces were processed in ascending grades of alcohol for dehydration and cleared in xylene. The paraffin embedded tissues were cut into 4-5 micron thick sections and stained with Haematoxylene and Eosin (H\&E) as per conventional procedure (Akkiv and Nilsson 1999).

\section{Statistical analysis}

All data were expressed as mean \pm SE (standard error). Data were assessed by using a one- way 
ANOVA using SPSS 15.0 program and $\mathrm{p}<0.05$ was considered statistically significant.

\section{RESULTS}

Glutathione peroxidase activity was determined in all groups as shown in table 1 . Significant difference was observed on all days post infection and post reinfection in infected group II as the mean values were $25.7 \pm 0.4,23.1 \pm 0.3,20.7 \pm 0.2$ and $18.4 \pm 0.5$ compared to normal control group I $(31.9 \pm 0.2)$. Vaccinated groups II and IV showed significant increase in all days compared to control infected group II and significant decrease compared to normal control group I. The mean values increases more in group IV (800 Gy). Regarding SOD levels (table 2), there was significant decrease in control infected group II in days $7^{\text {th }}, 14^{\text {th }}, 7^{\text {th }}(\mathrm{R})$ and $14^{\text {th }}(\mathrm{R})$ as they were $(3.8 \pm 0.1), \quad(4.0 \pm 02), \quad(3.5 \pm 0.3 \pm 0.3)$ compared to control normal group I $(5.9 \pm 0.06)$. Vaccinated groups II showed significant decrease than normal control and significant increase than infected control group in all days as they were $(5.1 \pm 0.1),(4.1 \pm 0.3),(3.9 \pm 0.2)$ and $(3.7 \pm \pm 0.1)$ respectively. In group IV irradiated with 800 Gy the mean values level were $(5.4 \pm 0.2)$, $(4.7 \pm 0.1), \quad(4.2 \pm 0.1)$ and $(3.8 \pm 0.1)$ respectively. Malondialdehyde levels increased significantly in all days of infected group II as they were $(145.4 \pm 1.5)$, $(150.7 \pm 1.4), \quad(164.6 \pm 2.1) \quad$ and $(171 \pm 2.9) \quad$ in comparison with the control normal group I $(117.5 \pm 2.1)$. Vaccinated group III gave significant increase than normal and significant decrease than infected group as the mean levels in days $7^{\text {th }}, 21$ th, $7^{\text {th }}$ (R) and 21th (R) were (125.1 \pm 2.4$),(127.5 \pm 3.5)$, $(130 \pm 3.7)$ and $(157.1 \pm 1.2)$ respectively while group IV with the higher dose of radiation, the values were
(122.1 \pm 2.3$),(133.3 \pm 1.5), 136.7 \pm 2.8)$ and $(146.2 \pm 2.5)$ respectively.

Biochemical studies table (4) shows the mean values of urea levels of group (II) it was $93.4 \pm 0.15^{\mathrm{a}}$ at $7^{\text {th }}$ day post infection and $100.6 \pm 2.1^{\mathrm{a}}$ at day $14^{\text {th }}$ post challenge which is highly significant increased $(\mathrm{P}<0.01)$ as compared to control normal group I (40.0 \pm 2.1$)$. Vaccinated group III showed significant increase compared to the normal control group and significant decrease relative to infected control one in both $7^{\text {th }}$ day and $7^{\text {th }}(\mathrm{R})$ as they were $63.2 \pm 1.6$ and $66.7 \pm 1.1$ respectively. Also, group IV gave 58.4 \pm 2.1 and $89.5 \pm 2.4$ with significant decrease compared to control infected group. Mean value of serum creatinine was $0.84 \pm 0.1$ in control normal group I and in control infected group II it was $1.3 \pm 0.15$ at $7^{\text {th }}$ and $1.5 \pm 0.15$ at $7^{\text {th }}(\mathrm{R})$ with significant increase compared to normal group. Vaccinated groups II and IV in both days $7^{\text {th }}$ and $7^{\text {th }}(\mathrm{R})$ showed $0.95 \pm 0.09,1.1 \pm 0.07$, $1.1 \pm 0.14$ and $0.97 \pm 0.06$ respectively with decrease in the levels than control infected group. Regarding total protein levels, there was significant increase in control infected group II in days $7^{\text {th }}$ and $7^{\text {th }}(\mathrm{R})$ as they were $6.6 \pm 0.3$ and $7.3 \pm 0.1$ respectively compared to normal group I $(6.1 \pm 0.5)$. Vaccinated groups III and IV showed no significant decrease compared to infected control group at $7^{\text {th }}$ day as they were $6.2 \pm 0.5$ and $5.8 \pm 0.4$ respectively while, the levels significantly decrease at day $7^{\text {th }}(\mathrm{R})(6.4 \pm 0.3)$ and $(6.3 \pm 0.3)$ respectively. Albumin level decrease in control infected group at both post infection and post challenge while globulin levels significantly increase in the same group compared to normal. Vaccinated groups III and IV showed slight elevation than normal level but less than control infected group in post infection and post challenge days.

Table 1: Glutathione (GSH) activities in kidney tissues of all exposed groups (U/gHb).

\begin{tabular}{ccccc}
\hline Droups & $7^{\text {th }}$ & $14^{\text {th }}$ & $7^{\text {th }}(\mathrm{R})$ & $14^{\text {th }}(\mathrm{R})$ \\
\hline Group I & $31.9 \pm 0.2$ & & & \\
\hline Group II & $25.78 \pm 0.4^{\mathrm{a}}$ & $23.12 \pm 0.3^{\mathrm{a}}$ & $20.73 \pm 0.2^{\mathrm{a}}$ & $18.44 \pm 0.5^{\mathrm{a}}$ \\
\hline Group III & $26.3 \pm 0.1^{\mathrm{ab}}$ & $24.89 \pm 0.1^{\mathrm{a}}$ & $22.91 \pm 0.1^{\mathrm{ab}}$ & $22.10 \pm 1.3^{\mathrm{ab}}$ \\
\hline Group IV & $29.14 \pm 0.2^{\mathrm{ab}}$ & $28.08 \pm 0.8^{\mathrm{ab}}$ & $27.52 \pm 1.2^{\mathrm{ab}}$ & $25.94 \pm 0.9^{\mathrm{ab}}$ \\
\hline
\end{tabular}

Table 2: SOD activities in kidney tissues all exposed groups (U/gHb).

\begin{tabular}{|c|c|c|c|c|c|}
\hline 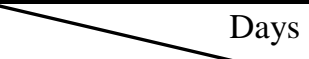 & & $7^{\text {th }}$ & $14^{\text {th }}$ & $7^{\text {th }}(\mathrm{R})$ & $14^{\text {th }}(\mathrm{R})$ \\
\hline Groups & & & & & \\
\hline Group I & $5.9 \pm 0.06$ & & & & \\
\hline Group II & & $3.82 \pm 0.1^{\mathrm{a}}$ & $4.06 \pm 0.2^{\mathrm{a}}$ & $3.50 \pm 0.3^{\mathrm{a}}$ & $3.21 \pm 0.3^{\mathrm{a}}$ \\
\hline Group III & & $5.13 \pm 0.1^{\mathrm{ab}}$ & $4.16 \pm 0.3^{\mathrm{a}}$ & $3.92 \pm 0.2^{\mathrm{ab}}$ & $3.71 \pm 0.1^{\mathrm{ab}}$ \\
\hline Group IV & & $5.40 \pm 0.2^{\mathrm{ab}}$ & $4.76 \pm 0.1^{\mathrm{ab}}$ & $4.27 \pm 0.1^{\mathrm{ab}}$ & $3.80 \pm 0.1^{\mathrm{ab}}$ \\
\hline
\end{tabular}


$\underline{\text { Assiut Vet. Med. J. Vol. } 61 \text { No. } 147 \text { October } 2015}$

Table 3: LPO activities in kidney tissues all exposed groups (U/gHb).

\begin{tabular}{lccccc}
\hline Droups & Days & $7^{\text {th }}$ & $14^{\text {th }}$ & $7^{\text {th }}(\mathrm{R})$ & $14^{\text {th }}(\mathrm{R})$ \\
\hline Group I & $117.5 \pm 2.1$ & & & \\
\hline Group II & $145.4 \pm 1.5^{\mathrm{a}}$ & $150.7 \pm 1.4^{\mathrm{a}}$ & $164.6 \pm 2.1^{\mathrm{a}}$ & $171 \pm 2.9^{\mathrm{a}}$ \\
\hline Group III & $125.1 \pm 2.4^{\mathrm{ab}}$ & $127.5 \pm 3.5^{\mathrm{ab}}$ & $130 \pm 3.7^{\mathrm{ab}}$ & $157.1 \pm 1.2^{\mathrm{ab}}$ \\
\hline Group IV & $122.1 \pm 2.3^{\mathrm{ab}}$ & $133.3 \pm 1.5^{\mathrm{ab}}$ & $136.7 \pm 2.8^{\mathrm{ab}}$ & $146.2 \pm 2.5^{\mathrm{ab}}$ \\
\hline
\end{tabular}

Values represented mean \pm SE of 5 rat in each group.

a: significant at $(\mathrm{P}<0.05)$ compared to control. b: significant compared to infected group

Table 4: Effect of T.canis on kidney functions of different groups.

\begin{tabular}{|c|c|c|c|c|c|c|}
\hline Groups & Days & Urea $(\mathrm{Mg} / \mathrm{dl})$ & $\begin{array}{l}\text { Creatinine } \\
(\mathrm{mg} / \mathrm{dl})\end{array}$ & $\begin{array}{l}\text { Total protein } \\
(\mathrm{g} / \mathrm{dl})\end{array}$ & $\begin{array}{l}\text { Albumin } \\
(\mathrm{g} / \mathrm{dl})\end{array}$ & $\begin{array}{l}\text { Globulin } \\
(\mathrm{g} / \mathrm{dl})\end{array}$ \\
\hline Group I & & $40.0 \pm 2.1$ & $0.84 \pm 0.1$ & $6.1 \pm 0.56$ & $2.2 \pm 0.15$ & $3.49 \pm 0.51$ \\
\hline \multirow[t]{2}{*}{$\begin{array}{l}\text { Group II } \\
\text { (Infected) }\end{array}$} & $7^{\text {th }}$ & $\begin{array}{c}93.4 \pm 0.15^{\mathrm{a}} \\
(133.5 \%)\end{array}$ & $\begin{array}{l}1.3 \pm 0.15^{\mathrm{a}} \\
(44.0 \%)\end{array}$ & $\begin{array}{l}6.6 \pm 0.3^{\mathrm{a}} \\
(24.5 \%)\end{array}$ & $\begin{array}{c}2.0 \pm 0.12 \\
(-8.0 \%)\end{array}$ & $\begin{array}{c}4.1 \pm 0.38^{\mathrm{a}} \\
(31.1 \%)\end{array}$ \\
\hline & $7^{\text {th }}(\mathrm{R})$ & $\begin{array}{c}100.6 \pm 2.1^{\mathrm{a}} \\
(154.6 \%)\end{array}$ & $\begin{array}{l}1.5 \pm 0.15^{\mathrm{a}} \\
(58.5 \%)\end{array}$ & $\begin{array}{l}7.3 \pm 0.15^{\mathrm{a}} \\
(13.7 \%)\end{array}$ & $\begin{array}{r}2.2 \pm 0.10^{\mathrm{a}} \\
(-9.0 \%)\end{array}$ & $\begin{array}{c}5.21 \pm 0.17^{\mathrm{a}} \\
(46.5 \%)\end{array}$ \\
\hline \multirow[t]{2}{*}{$\begin{array}{c}\text { Group III } \\
\text { (600Gy IRR) }\end{array}$} & $7^{\text {th }}$ & $\begin{array}{c}63.2 \pm 1.6^{\mathrm{ab}} \\
(58.0 \%)\end{array}$ & $\begin{array}{c}0.95 \pm 0.09^{\mathrm{ab}} \\
\quad(13.0 \%)\end{array}$ & $\begin{array}{l}6.2 \pm 0.5 \\
(1.6 \%)\end{array}$ & $\begin{array}{c}2.6 \pm 0.13 \\
(4.0 \%)\end{array}$ & $\begin{array}{l}3.5 \pm 0.2 \\
(1.44 \%)\end{array}$ \\
\hline & $7^{\text {th }}(\mathrm{R})$ & $\begin{array}{c}66.7 \pm 1.1^{\mathrm{ab}} \\
(68.8 \%)\end{array}$ & $\begin{array}{c}1.1 \pm 0.07^{\mathrm{ab}} \\
(34.1 \%)\end{array}$ & $\begin{array}{l}6.4 \pm 0.3^{\mathrm{b}} \\
(10.3 \%)\end{array}$ & $\begin{array}{c}2.4 \pm 0.20 \\
(11.3 \%)\end{array}$ & $\begin{array}{c}3.4 \pm 0.18^{\mathrm{b}} \\
(6.25 \%)\end{array}$ \\
\hline \multirow[t]{2}{*}{$\begin{array}{c}\text { Group IV } \\
\text { (800 Gy IRR) }\end{array}$} & $7^{\text {th }}$ & $\begin{array}{c}58.4 \pm 2.1^{\mathrm{ab}} \\
(46.0 \%)\end{array}$ & $\begin{array}{c}1.10 \pm 0.14^{\mathrm{ab}} \\
(30.9 \%)\end{array}$ & $\begin{array}{c}5.8 \pm 0.43 \\
(-4.9 \%)\end{array}$ & $\begin{array}{c}2.3 \pm 0.15 \\
(-8.0 \%)\end{array}$ & $\begin{array}{l}3.2 \pm 0.13 \\
(-8.3 \%)\end{array}$ \\
\hline & $7^{\text {th }}(\mathrm{R})$ & $\begin{array}{c}89.5 \pm 2.4^{\mathrm{ab}} \\
(126.5 \%)\end{array}$ & $\begin{array}{c}0.97 \pm 0.06^{\mathrm{ab}} \\
(18.2 \%)\end{array}$ & $\begin{array}{c}6.3 \pm 0.3^{\mathrm{b}} \\
(8.6 \%)\end{array}$ & $\begin{array}{c}2.35 \pm 0.18 \\
(4.5 \%)\end{array}$ & $\begin{array}{c}3.3 \pm 0.2^{\mathrm{b}} \\
(3.1 \%)\end{array}$ \\
\hline
\end{tabular}

Values represented mean $\pm \mathrm{SE}$ of 5 rat in each group.

a: significant at $(\mathrm{P}<0.05)$ compared to control. b: significant compared to infected group

Histopathology Histopathological section from kidney of normal rat group I (fig. 1) shows normal renal structure regarding gloeruli and their tufts, renal tubules, blood vessels and intra-tubular connective tissue. Group II of rat that infected with egg (+ve control) showed a larva migrans replaced the renal parenchyma which showing degenerative changes (fig. 2). Congestion of glomerular tufts and distension of Bowman'space was shown in (fig. 3). Fig. 4 shows no histopathological changes in vaccinated groups. 


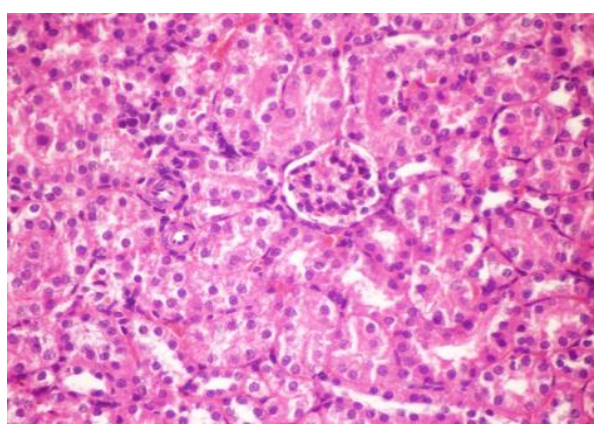

Fig. 1: Kidney of group I revealed normal renal structure regarding gloeruli, their tufts, renal tubules, blood vessels and connective tissue. (H\&E X400)

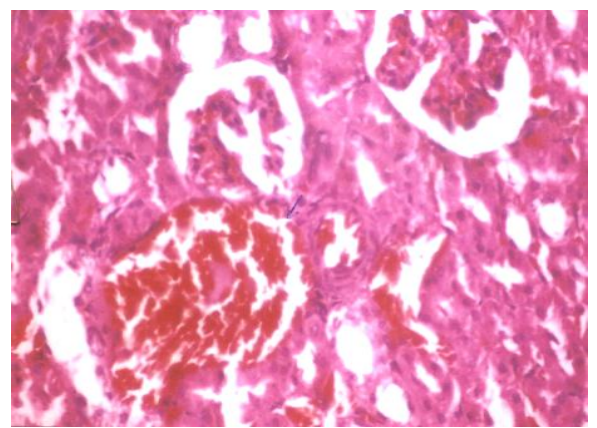

Fig. 3: Kidney of rat from control infected group II showing congestion of renal blood vessel and necrobiosis of tubular epithelium. (H\&E X400)

\section{DISCUSSION}

The use of ionizing radiation in the production of irradiated attenuated vaccines against parasitic infestations has been taken into consideration since the last five decades. The irradiated attenuated vaccines represent a recent successful and promising approach in control of the parasitic diseases.

The present results indicated that gamma radiation can be used to attenuate $T$. canis eggs to produce vaccine against infection with effective stage of $T$. canis eggs. Also, in this study, gamma rays at dose of 800 Gy proved that it causes some sort of increasing immunity of the body against new infection, since histopathological changes observed in the kidney were much less in this group. This may be due to a reduction in the rate of migration of the larvae to the tissues of infected rats, or due to immunization of the body against infection by the attenuated eggs. This is in agreement with previous study used UV radiation for attenuating the infective stage of the parasite (Ruppel et al., 1990). Also, another study stated that irradiation of infective $T$. canis larvae reduces their pathogenicity, inhibits their migration from liver and lungs, and kills some of the parasites during the first 3 weeks of infection (Barriga and Myser, 1987).

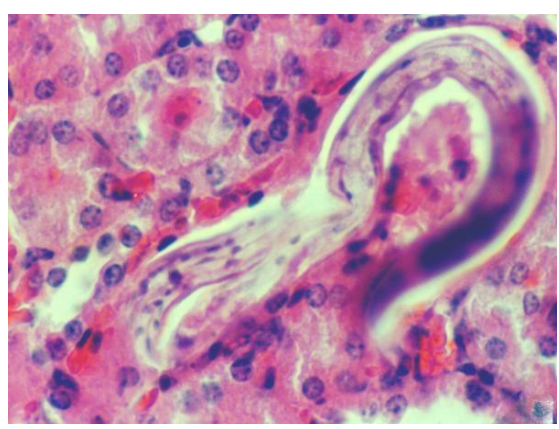

Fig. 2: Kidney of rat from control infected group II showing larva migrans replaced the renal parenchyma which showing degenerative changes. (H\&E X400)

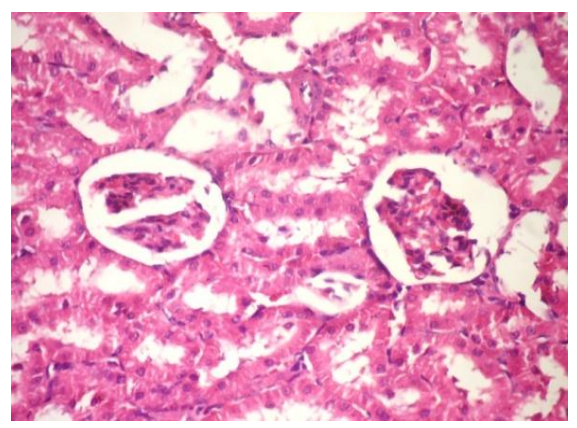

Fig. 4: Kidney of rat from vaccinated groups showing no pathological changes

Naguib and Amin, (2006) reported that damage in the eyes caused by infection with $T$. canis decreased by increasing the dose of irradiation of the infected stage.

Although oxidation reactions are crucial for life, they can also be damaging as they can produce reactive oxygen species that damage cells by chain reactions through lipid peroxidation, or by oxidizing DNA or proteins (Sies, 1997). Damage to DNA can cause mutations and possibly cancer, if not reversed by DNA repair (Nakabeppu et al., 2006). Oxidative stress is terminated by antioxidant system which stops these chain reactions by being oxidized themselves (Valko et al., 2007).

Lipid peroxidation is a degenerative process which affects the polyunsaturated fatty acids of membrane phospholipids. The general mechanism of this process involves the formation of toxic aldehydes, which react with protein and non-protein substances and result in widespread changes in cellular membranes. These degenerative processes can be prevented molecularly (vitamin A, vitamin $\mathrm{C}$, vitamin $\mathrm{E}$, uric acid, ceruloplasmin) and enzymatically (Cu-Zn SOD, GSH-Px, and catalase). Therefore lipid peroxidation can be estimated directly by determination of reactive oxygen species (hydroxyl, superoxide anion, $\mathrm{H}_{2} \mathrm{O}_{2}$ 
and single reactive oxygen radicals) or MDA levels in plasma, tissues and erythrocytes (Yarsan, 1998).

In the present study, we evaluated the lipid peroxidation in mice which were infected with $T$. canis, and vaccinated with different doses of gamma irradiated eggs. The estimation was done by determining MDA levels, GSH-Px, and SOD activities in kidney homogenate on days $7^{\text {th }}$ and $14^{\text {th }}$ post infection and post challenge. The results showed that a significant increase kidney LPO tissue of group II infected with non irradiated $T$. canis eggs, accompanied by significant decreases in SOD and GSH content. This is due to parasitic infections are associated with significant degree of free radicals formation as indicated by significantly higher MDA and lower SOD levels among those rats. While, in irradiated (600 Gy and $800 \mathrm{GY}$ ) infected eggs groups III and IV respectively showed a significant decrease in LPO and increases SOD and GSH in kidney tissue as compared to infected control group II. The data obtained by Yarsan et al. (2003) who showed that $T$. canis infection stimulates lipid peroxidantion and decreased glutathione peroxidase, superoxide dismutase and catalase activity in erythrocytes.

Lipid peroxidation, super oxide dismutase and glutathione production are important under the oxidative stress conditions, and many pathological disorders and infections can cause oxidative stress. It was found that, $S$. mansoni infected mice and all immunized groups recorded significant increase in lipid peroxides, while significant decrease in glutathione content was observed, also they found that in post challenged groups, the antioxidant levels recorded significant improvement in mice immunized by saponin (Maghraby et al., 2010).

Previous study reported that oxidative stress due to schistosomiasis causes an elevation in lipid peroxides. Also they showed that liver GSH was drastically depleted in S. mansoni infected mice (Pascal et al., 2000 and Hamed 2006). This decrease was attributed to the increased cytotoxicity with $\mathrm{H}_{2} \mathrm{O}_{2}$ produced as a result of inhibition of glutathione reductase that keeps glutathione in the reduced state (Gharib et al., 1999). $S$. mansoni infection impairs the antioxidant system since the level of GSH depletion was used as an index of oxidative stress and a sign that hepatic cells are utilizing more antioxidant defenses (Ip et al., (2000). Also, significant reduction in the levels of activities of SOD, Catalase, total Glutathione peroxidase and vitamin $\mathrm{E}$ in fascioliasis cases in comparison to control (EL Shazly et al., 2014). It was reported that most of the pathologic features associated with Toxocara infection resulted from the damage of tissue caused by immune-mediated inflammatory response and biologically active products such as proteases released by larvae (Buijs et al., 1997 and Smith, 1993). This is harmony with the fact that re-infection with the results of the present work indicated that, the mean levels of serum creatinine, urea and protein activities have been found generally to increase significantly in most of the infected rat group II in comparison with that of the control normal group I. This may be attributed to complications arising from the extensive larval migration inside the body tissues especially the liver parenchyma and other tissues. Also, this was in accordance to a study that reported an increase in level of blood urea and serum creatinine in patient presented by severe asthma as a result of visceral larva migran associated with hyper eosinophilia (Feldman and Parker 1992). Although reported that people who were positive for Toxocara infection had higher alkaline phospatase but serum creatinine and blood urea found to be in normal range and they are not determining factors in Toxocara infection and renal dysfunction in heavy infection with toxocariasis (Dar et al., 2009 and Pol Merkur, 2008).

Histopathological examination of kidney of rats, after infection with Toxocara canis eggs revealed various pictures of pathological affection. There was diffuse mesangioproliferative glomerulonephritis with mesangeal expansion of most of glomeruli. Some glomeruli showed severe hyalinosis with marked adhesions to the bowman's capsule. The lumina of glomerular capillaries were markedly obliterated. There was also cystic dilatation of tubules with proteinaceous casts. The intersitial tissue showed mild inflammatory oedema. Chronic inflammatory cellular infiltration to form granulomatous inflammation was noticed. This was in agreement with Casarosa et al. (1992) who reported that histological examination of kidneys from mice experimentally infected with Toxocara canis embryonated eggs demonstrated the presence of a segmental or diffuse mesangioproliferative glomerulonephritis. Immunohistochemical studies established that renal alterations were associated with glomerular deposits of IgG, IgM and third component of complement (C3) and these findings suggest that an immunomediated mechanism might possibly be involved in the genesis of kidney damage observed in mice infected with $T$. canis embryonated eggs.

These histopathological changes caused by infection with $T$. canis decreased by increasing the dose of irradiation of the infected stage, radiation exposure attenuated the larval migration from the gastrointestinal tract to the other organs. The above results showed that irradiated $T$. canis eggs give a degree of protection in kidney of rats that re-infected with $T$. canis. This may be due to the effect of irradiation on the parasite which retards the development of its larvae, these larvae might be too weak to produce comparable damages as those which were not irradiated. 
Previous study on the effect of radiation on the viability and migratory ability of second-stage larvae of Toxocara canis in mice reported that most of the larvae irradiated with 80 or $160 \mathrm{Krad}$ remained in the digestive tract, mainly in the stomach and the proximal half of the small intestine (Kamiya et al., 1987). It was reported that irradiation of infective $T$. canis larvae, then, reduces their pathogenicity, inhibits their migration from liver and lungs, kills some of the parasites during the first 3 weeks of infection, but favors their late survival in the host (Barriga and Myser, 1987).

It was concluded that vaccination with Toxocara canis eggs irradiated with $800 \mathrm{~Gy}$ gamma radiation ameliorate the biochemical, haematological and histopathological of renal toxocariasis.

\section{ACKNOWLEDGMENT}

This work was done and supported by National Center for Radiation, Research and Technology that provides gamma and UV radiation source and all experiments were done in animal house. All authors contribute for this research as Dr Mervat moawad designed the research study; and wrote the paper. Dr Mona Mohamed Amin contributed essential reagents or tools and analyzed the data. Dr Eman Naser Hafez analyzed the data and wrote the paper.

\section{REFERENCES}

Akkivft, A. and Nilsson, B.O. (1999): Biological effects of aminoguanidine: an update. Inflamm. Res. (48), 509-515,

Alderet, J.M.S.; Yamashiro, E.H. and RubiskyElafant, G. (1999): Aspectos epidemiologicos da toxocariase em escolares do subdistrito do Butanta, zona oeste de sao Paulo. Rev Soc. Bras. Med. Trop. 32 (1) 316 - 317.

Alonso, J.M.; Bajanich, M.V.I. and Chamorro, M. (2000): Toxocara seroprevalence in children from a subtropical city in Argentina. Rev. Inst. Med. Trop. Sao Paulo (44) 303- 307.

Barriga, O.O. and Myser, W.C. (1987): Effects of irradiation on the biology of the infective larvae of Toxocara canis in the mouse. Journal of Parasitology ; 73(1), 89-94.

Beutler, E.; Duran, O. and Kelly, B.M. (1963): Improved method for the determination of blood.

Buege, J.A. and Aust, S.D. (1978): Microsomal lipid peroxydation. Methods Enzymol. (12), 302310.

Buijs, J.; Borsboom, G. and Renting, M. (1997): Relationship between allergic manifestations and Toxocara seropositivity: a cross-sectional study among elementary school children. European Respiratory Journal, (7), 1467-75,

Casarosa, L.; Papini, R. and Mancianti, F. (1992): Renal involvement in mice experimentally infected with Toxocara canis embryonated eggs. Vet Parasitol 42(3-4), 265-72.

Dar, Z.A.; Tanveer, S. and Yattoo, G.N. (2009): Alkaline Phosphatase in Serum is a Marker of Human Toxocariasis, $I J B C(2)$, 59-62.

El Shazly, A.A.; Hegazi, M.A. and AbdRaboo, M.A. (2014): Impact of human fascioliasis on oxidative stress, J. Nucl. appl. Sci. (3), 295303

El-Sokkary, G.H.; Omar, H.M. and Hassanein, A.M.M. (2002): Melatonin reduces oxidative damage and increases survival of mice infected with Schistosoma mansoni. Free Radic. Biol. Med. (32) 319-332.

Espinosa, E.; Perez Arellano, J.L. and Ciarranza, C. (2002): In vivo inhibition of inducible nitric oxide synthase decreases lung injury induced by Toxocara canis in experimentally infected rats. Parasit. Immunol. (24), 511-520.

Feldman, G.J. and Parker, H.W. (1992): Visceral Larva Migrans Associated with the Hypereosinophilic Syndrome and the Onset of Severe Asthma. Ann Intern Med. (10), 838840.

Fortenberry, J.D.; Kenney, R.D. and Younger, J. (1991): Visceral larva migrans producing static encephalopathy. Pediatr. Inf. Dis. J 10 (5) 403-406.

Galvin, T. (1964): Experimental Toxocara canis infections in chickens and pigeons. $J$. Parasitol. (50), 124-127.

Gharib, B.; Abd-Allah, O.M. and Dessein, H. (1999): Development of eosinophil peroxidase activity and concomitant alteration of antioxidant defenses in the liver of mice infected with Schistosoma mansoni. Journal of Hepatolology, (30), 594- 602.

Glickman, L. (1993): The epidemiology of human toxocariasis. in J.W. Lewis, and R.M. Maizels, (Eds.), Toxocara and toxocariasis: clinical, epidemiological and molecular perspectives. London. 55-61.

Glickman, L.T.; Chaudry, I.U. and Costantino, J. (1981): Pica patterns, toxocariasis and elevated blood lead in children. Am. J. Trop. Med. Hyg; ; (30) 81-3.

Hamed, M.A. (2006): Excretory-secretory product of Fasciola hepatica worm protects against Schistosoma mansoni infection in mice. Indian J. of Exp. Biolo; (44) 554-561.

Ip, S.; Yiu, H.Y. and Kos, K.M. (2000): Differential effect of schisandrin B and dimethyl diphenyl bicarboxylate (DDB) on hepatic mitochondrial glutathione redox status in carbon tetrachloride intoxicated mice. Molecular and Cellular Biochemistry, (205) 111- 114.

Kamiya, M.; Ooi, H.K. and Nomura, T. (1987): The effect of radiation on the viability and migratory ability of second-stage larvae of 
Toxocara canis in mice. Vet Parasitol. (24), 87-92.

Kaneko, J. (1989): Clinical biochemistry of domestic animals. San Diego, California, Academic Press. in Kaneko, J. (Ed.), 886-891.

Maghraby, A.S.; Hamed, M.A.A. and Aly, H.F. (2010): The Antischistosomal Activity of Fasciola gigantica and Schistosolma mansoni Eggs is Influenced by Saponin Extracted from Atriplex nummularia, Journal of American Science, (8), 368-381.

Naguib, N.I. and Amin, M.M. (2006): Studies of ocular toxocariasis in rats infected with irradiated toxocara canis eggs. Isotope \& Rad. Res., (38), 981-991.

Nakabeppu, Y.; Sakumi, K. and Sakmoto, K. (2006): "mutagenesis and carcinogenesis caused by the oxidation of nucleic acids" Biol. Chem. 387(4), 373.

Oliveira, F.J. and Cecchini, R. (2000): Oxidative stress of liver in hamsters infected with Leishmania (L.) chagasi. J. Parasitol. (86) 1067-1072,

Pascal, M.; Abd-Allah, O.M. and El-Wali, N.E. (2000): Hyaluronate levels and markers of oxidative stress in the serum Sudanese subjects at risk of infection with Schistosoma mansoni. Transactions of the Royal Society of Tropical Medicine and Hygiene (94), 66-70.

Pawlowski, Z. (2007): Toxocariasis in in humans. Clinical expression and treatment dilemma. J. Helminthol. (75) 299 - 305.

Pol Merkur L. (2008): Atypical manifestation of toxocariasis in 17-year-old boy--a case report. Scientific research pub. (144), 533-5.

Rajan, T.V.; Porte, P. and Yates, J.A. (1996): Role of nitric oxide in host defence against an extracellular, metazoan parasite, Brugia malayi. Infect. Immun. (64) 3351-3353.
Rothenberg, M.E. (1998): Eosinophilia. N. Eng. J. Med. (388) $1592-1600$.

Ruppel, A.; Shi, Y.E. and Molony, N.A. (1990): Schistosoma mansoni and $S$. japonicum comparison of levels of ultraviolet irradiation for vaccination of mice with cercariae. parasit., (3), 101-123.

Selkirk, M.E.; Smith, V.P. and Thomas, G.R. (1998): Resistance of filarial nematode parasites to oxidative stress. Int. J.Parasitol. (28), 13151332.

Sies, H. (1997): Oxidative stress: oxidants and antioxidants, Exp.Physio. 82(2), 291.

Smith, H.V. (1993): Antibody reactivity in human toxocariasis. In: Lewis JW, Maizels RM (eds) Toxocara and toxocariasis. Clinical, epidemiological and molecular perspectives. British Society for Parasitology and Institute of Biology, 91-109

Sun, Y.; Oberley, L.W. and Li, Y.A. (1988): Simple method for clinical assay of superoxide dismutase. Clin. Chem. (34), 497-500.

Taylor, M.R.H. and Holland, C.V. (2001): Toxocariasis: Principles and practice of Clinical Parasitology. Gillespie SH, Pearson RD, eds). New York (NY): John Wiley and Sons, $\mathrm{Lt}$;

Valko, M.; Leibfritz, D. and Moncol, J. (2007): Free radicals and antioxidants in normal physiological functions and human disease. Int. J. Biochem. Cell Biol. 39(1):44.

Yarsan, E. (1998): Lipid peroxidation and prevention process. J. Vet. Med. (9), 89-95.

Yarsan, E.; ALtinsaat, I. and Hasan, A.U.E. Pahundokuyucu, F. and Kalkav, F. (2003): Effects of Albendazole Treatment on Haematologicaland Biochemical Parameters in Healthy and Toxocara canis Infected Mice. Turk J. Vet. Anim Sci, 39(1), 44.

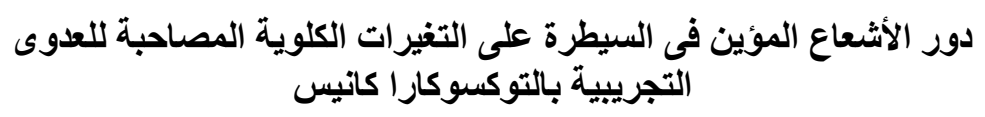

\section{ميرفت عبل الفتاح معوض ، منس محمد أمبن ، ابيان ناصر حافظ}

Email: Eman_naser612@hotmail.com Assiut University web-site: www.aun.edu.eg

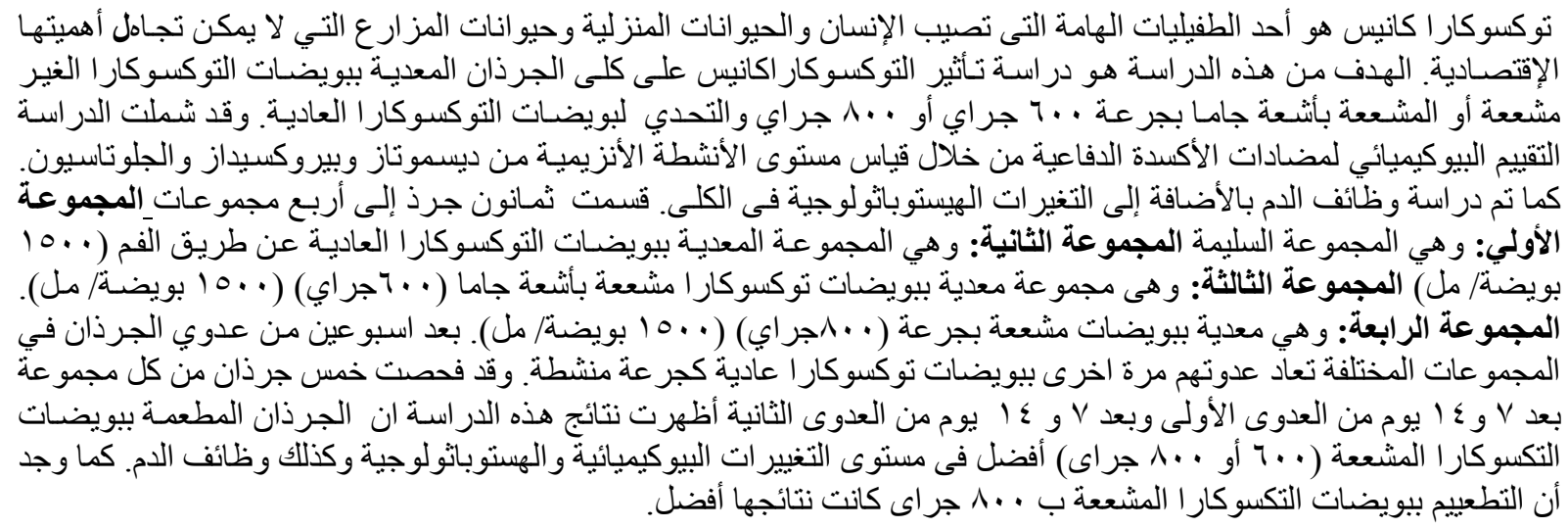

